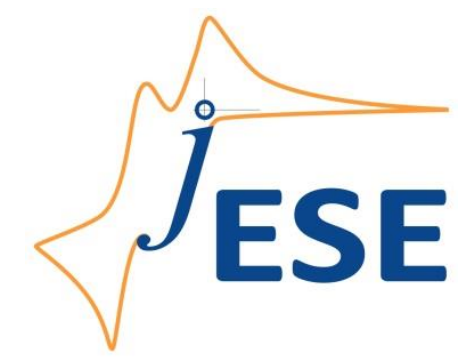

Open Access : : ISSN 1847-9286

www.jESE-online.org

Original scientific paper

\title{
Inhibition of mild steel corrosion using Jatropha Curcas leaf extract
}

\author{
OLORUNFEMI MICHAEL AJAYY ${ }^{\bowtie}$, JAMIU KOLAWOLE ODUSOTE*, \\ RAHEEM ABOLORE YAHYA*
}

Department of Mechanical Engineering, University of Ilorin, Ilorin, Nigeria

*Department of Materials and Metallurgical Engineering, University of Ilorin, Ilorin, Nigeria

${ }^{\otimes}$ Corresponding Author: E-mail: ajayimichael2012@gmail.com; Tel.: +2348035231400

Received: August 13, 2013; Revised: February 19, 2014; Published: May 13, 2014

\begin{abstract}
Jatropha Curcas leaf was investigated as a green inhibitor on the degradation of mild steel in 4 $\mathrm{M} \mathrm{HCl}$ and $4 \mathrm{M} \mathrm{H}_{2} \mathrm{SO}_{4}$ aqueous solutions using gasometric technique. Mild steel coupons of dimension $2 \times 1.5 \mathrm{~cm}$ were immersed in test solutions of uninhibited acid and also those with extract concentrations of $4 \mathrm{ml}, 6 \mathrm{ml}, 8 \mathrm{ml}$ and $10 \mathrm{ml}$ at $30{ }^{\circ} \mathrm{C}$, for up to 30 minutes. The results showed that as the concentration of the extract increases, there was reduction in the corrosion rate. As the extract concentration increased from $4 \mathrm{ml}$ to $10 \mathrm{ml}$ at 30 minutes exposure, the volume of hydrogen gas evolved decreased from $19.1 \mathrm{~cm}^{3}$ to $11.2 \mathrm{~cm}^{3}$ in $\mathrm{H}_{2} \mathrm{SO}_{4}$ medium, while it reduced to $5 \mathrm{~cm}^{3}$ from $9 \mathrm{~cm}^{3}$ in $\mathrm{HCl}$ medium. Also, the metal surface-phytoconstituent interaction mechanism showed that 6 minutes is the best exposure time for the adsorption of the extract in both acidic media. The Jatropha Curcas leaf extract was adsorbed on the mild steel surface to inhibit corrosion, while the experimental data obtained at 30 minutes exposure in both acidic media were well fitted with the Langmuir adsorption isotherm. Hence, Jatropha Curcas leaf extract is a good and safe inhibitor in both acidic solutions.
\end{abstract}

\section{Keywords}

Gasometric, Inhibitor, adsorption, mild steel, Langmuir isotherm

\section{Introduction}

Mild steel is a material commonly used in industries due to its low cost, availability and excellent mechanical properties [1]. However, the major drawback to its application is corrosion attack, which usually leads to structures degradation, equipment shutdown, loss of machines efficiency, and loss of valuable products, to mention but few [2]. The average corrosion cost has been reported to be about 3.5-4.5\% of the Gross National Product of most industrialized nations [3]. 
Corrosion can be prevented in several ways but the use of inhibitors is one of the most acceptable practices. The use of synthetic inhibitors has been seriously discouraged due to its high cost, non-biodegradability and harmfulness. Hence, naturally occurring compounds from plants origin have been a subject of interest for researchers because of their abundant availability, cost effectiveness and environmentally friendly [4]. Several studies have been carried out on the use of these naturally occurring compounds as corrosion inhibitors for metals in different media [5-19].

Jatropha Curcas (JC) is a perennial, multi-purpose and drought resistant plant that belongs to the family of Euphorbiaceous JC is also a tropical plant that can be grown in low to high rainfall regions [20], on both fertile and even in less fertile soil. Jatropha oil, obtained by crushing the seeds is used as biodiesel fuel. The plant is planted by farmers all over the world, because it is not browsed by animals. Non-toxic variety of Jatropha could be a potential source of oil for human consumption and the seed cake can be a protein source for humans as well as for livestock [21]. Another potential application of the leaves as corrosion inhibitor for mild steel in acidic media is established in this study.

\section{Experimental Procedure}

The chemical composition of the mild steel specimen used for this experiment in wt $\%$ is $0.17 \%$ C, $0.21 \% \mathrm{Si}, 0.55 \% \mathrm{Mn}, 0.02 \% \mathrm{P}, 0.02 \% \mathrm{~S}, 0.18 \% \mathrm{Cu}, 0.01 \% \mathrm{Ni}, 0.02 \% \mathrm{Sn}$ and $98.81 \% \mathrm{Fe}$. Specimens were press cut into pieces with dimension of $1.5 \times 2 \mathrm{~cm}$ coupons. The specimens were polished using LINN MAJOR STRUER-ITALY (Model No. 224732) with emery papers 140/0304 $140 / 0308$ grades. Subsequently, they were degreased in ethanol, dried in acetone and stored in desiccators. The solutions of $\mathrm{HCl}$ and $\mathrm{H}_{2} \mathrm{SO}_{4}$ were prepared by using double distilled water. The fresh leaf of Jatropha Curcas (JC) plant was taken, washed under running water, cut into pieces, air dried and then grounded well and sieves into powdery form. Then, $10 \mathrm{~g}$ each of the powdery leaf was put into flat bottom flask containing $200 \mathrm{~cm}^{3}$ of $4 \mathrm{M} \mathrm{HCl}$ and $\mathrm{H}_{2} \mathrm{SO}_{4}$ aqueous solutions. This concentration was used in order to fasten the rate of reaction between the metal surface and the acidic extract of the inhibitor within the period of the experiment. The resulting solutions were refluxed for 2 hours and left overnight before it was carefully filtered. The stock solution was prepared from the filtrate and into the desired concentrations. In this study, extract amount of 4-10 ml correspond to $0.2 \mathrm{~g} \mathrm{dm}^{-3}, 0.3 \mathrm{~g} \mathrm{dm}^{-3}, 0.4 \mathrm{~g} \mathrm{dm}^{-3}$ and $0.5 \mathrm{~g} \mathrm{dm}^{-3}$, respectively.

The gasometric assembly used for the measurement of hydrogen evolution was as reported by Aisha et al. [22]. A reaction vessel was connected to a burette through a delivery tube. The $4 \mathrm{M}$ $\mathrm{HCl}$ solution was introduced into the mylius cell, and the initial volume of air in the burette was recorded. Then, mild steel coupon was dropped into the $\mathrm{HCl}$ solution, and the mylius cell was quickly closed. The volume of hydrogen gas evolved from the corrosion reaction was monitored by the volume change in the level of water in the burette. The change in volume was recorded every 120 seconds for up to 30 minutes. Similar procedure was repeated with the inhibitor. The same experimental procedure was followed for $4 \mathrm{M} \mathrm{H}_{2} \mathrm{SO}_{4}$ solution.

The inhibition efficiency and the degree of surface coverage were determined using Equations 1 and 2 [21]:

$$
\begin{aligned}
& \text { Inhibition efficiency (I.E.), } \%=\frac{V_{\mathrm{HO}}-V_{\mathrm{H} 1}}{V_{\mathrm{HO}}} \times 100 \\
& \text { Surface coverage - } \theta=\frac{V_{\mathrm{HO}}-V_{\mathrm{H} 1}}{V_{\mathrm{HO}}}
\end{aligned}
$$


where $V_{\mathrm{HO}}$ is the volume of $\mathrm{H}_{2}$ gas evolved without inhibitor and $V_{\mathrm{H} 1}$ is the volume of $\mathrm{H}_{2}$ gas evolved with inhibitor.

\section{Results and discussion}

Figure 1 shows the variation of volume of hydrogen gas evolved with time for the corrosion of mild steel in various concentrations of the inhibitor in $\mathrm{HCl}$ aqueous solution. As shown in the figure, the hydrogen gas was not evolved in the first 8 minutes due to slow rate of corrosion reaction at the initial stage resulting from the inability of the acidic extract to quickly penetrate the metal surface. Above this exposure time, the volume of hydrogen gas evolved increased with increasing period of exposure, but decreases with increasing concentration of acidic extract of Jatropha Curcas leaf. The volume of hydrogen gas evolved at 30 minutes was $21.8 \mathrm{~cm}^{3}$ for the blank solution, while that of $4 \mathrm{ml}, 6 \mathrm{ml}, 8 \mathrm{ml}$ and $10 \mathrm{ml}$ concentrations of Jatropha Curcas leaf extract are $9.0,8.0,6.8$ and $5.0 \mathrm{~cm}^{3}$, respectively. This shows that oxide film developed faster on the surface of mild steel coupon with higher inhibitor concentration, and thus reduces the corrosion rate. The blank system having no inhibitor gave the highest hydrogen gas evolution and is far apart when compared to when varying concentration of the extract of Jatropha Curcas leaf was added. This may be due to the absence of inhibitor that will prevent acidic solution from reaching the metal surface [22]. Presence of oxide film causes the rate of hydrogen gas evolution to decrease (i.e. decrease in the rate of corrosion) [22]. Aisha et al. [21] also opined that increase in hydrogen evolution gas in the blank system may be due to direct reaction between the acid and the metal, since there is no adsorption layer to inhibit the reaction. Hence, the rate of hydrogen gas evolution, that is, the corrosion rate will be faster in the blank solution as compared with the inhibited. Ulaeto et al. [11] found that the leaf and root extracts of Eichornia Crassipe effectively inhibited the corrosion of mild steel in $5 \mathrm{M} \mathrm{HCl}$, and that the extracts performed better at higher concentration.



Figure 1. Variation of volume of $\mathrm{H}_{2}$ evolved with time of mild steel coupons for different volumes of $\mathrm{JC}$ extract in $4 \mathrm{M} \mathrm{HCl}$ solution

The variation of inhibition efficiency against time of immersion with varying concentration of the inhibitor in $4 \mathrm{M} \mathrm{HCl}$ aqueous solution is shown in Figure 2. The results show that from 0 to 
4 minutes, the inhibition efficiency was $0 \%$, corresponding to the latency period [23]. The corrosion rate was faster at the initial stage above 4 minutes, resulting in higher inhibition efficiency. However, at 6 minutes there was a re-ordering of the inhibition efficiencies from highest to the least value in descending order of the inhibitor concentration i.e. $(10 \mathrm{ml}<8 \mathrm{ml}<6 \mathrm{ml}<4 \mathrm{ml}$ ) at all the exposure times. This revealed that there is an adsorption of the constituents of the Jatropha Curcas leaves extract on the surface of mild steel with $10 \mathrm{ml}$ concentration of the inhibitor having the highest inhibition efficiency. The adsorption of the constituents resulted in the steady rate of corrosion (Fig. 2) due to the formation of oxide film separating the metal surface from the corrosive medium. Aisha et al. [21] investigated the use of Plectranthus Tenuifloros (Sahara) plant as safe and green inhibitor of mild steel corrosion in acidic solutions and observed that as the concentration of the extract increases, the inhibition efficiency increases. This was reported to be due to the adsorption layer formed on the surface of mild steel which inhibits the rate of corrosion. It was reported by Kuznetsov [23] that the longer the latency period, the higher the inhibition efficiency.

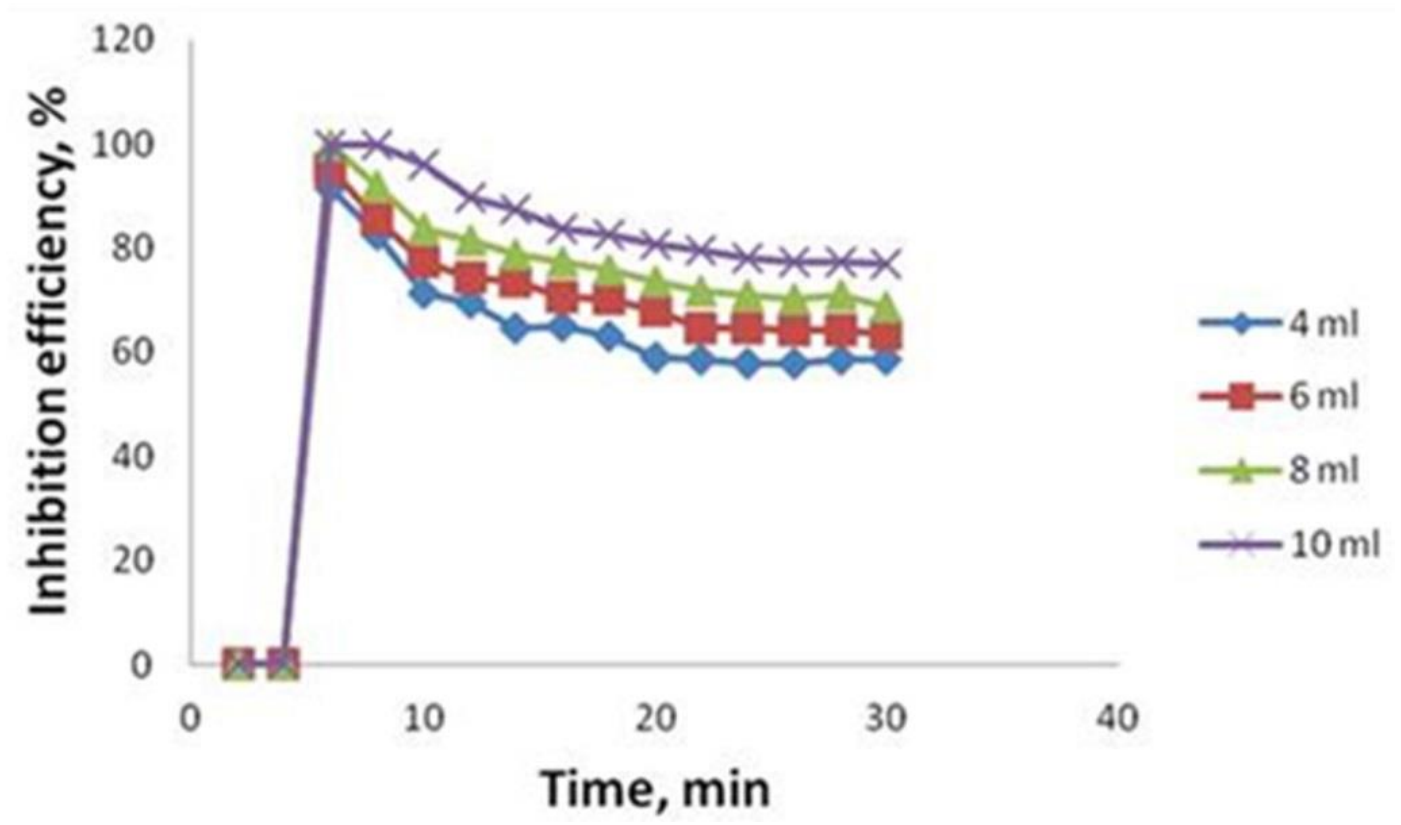

Figure 2. Variation of inhibition efficiency with the time of immersion in $4 \mathrm{M} \mathrm{HCl}$.

Figure 3 shows the variation of the volume of hydrogen gas evolved with time of exposure in sulphuric acid solution. The results revealed that the corrosion rate of mild steel as indicated by the amount of $\mathrm{H}_{2}$ gas evolved decreased in the presence of Jatropha Curcas leaf extract when compared to the control. The volume of hydrogen gas for blank solution was the highest as compared to those with different concentrations of Jatropha Curcas leaf extract. This infers that the $\mathrm{JC}$ leaf extract in the solution had a retarding effect on the corrosion of mild steel in $\mathrm{H}_{2} \mathrm{SO}_{4}$. Thus, the degree of inhibition can be said to be governed by the amount of JC extract present. The $10 \mathrm{ml}$ concentration of the inhibitor was able to reduce the rate of hydrogen gas evolution further due to the formation of more adsorption layer on the surface of mild steel sample. The trend agrees with the result of Eddy et al. [10] during the determination of the inhibition efficiency of ethanol extract of Phyllanthus Amarus on corrosion of mild steel in $\mathrm{H}_{2} \mathrm{SO}_{4}$ solution. They reported that the volume of hydrogen decreased as the concentrations of Phyllanthus Amarus increased and the highest concentration of $0.5 \mathrm{~g} / \mathrm{L}$ gave the least value of hydrogen gas evolution. 


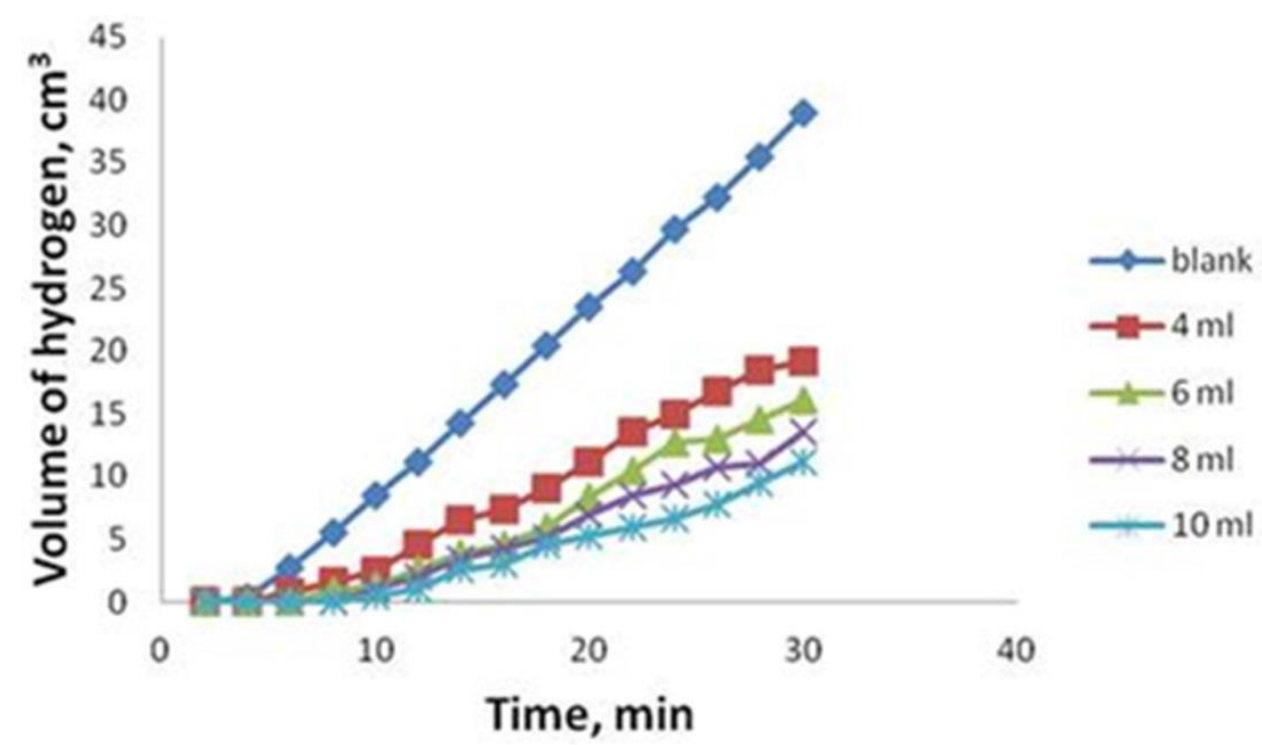

Figure 3. Variation of volume of $\mathrm{H}_{2}$ evolved with time of mild steel in coupons for different volumes of $\mathrm{JC}$ extract in $4 \mathrm{M} \mathrm{H}_{2} \mathrm{SO}_{4}$.

Figure 4 shows the variation of percentage inhibition efficiency with time of immersion in sulphuric acid solution. The results obtained revealed that the inhibition efficiency increases as the concentration of Jatropha Curcas leaf extract increases, which follow similar trends with results in $\mathrm{HCl}$ medium. Similar observations were made when gravimetric method was used [24]. Also, from 6 minutes there was a re-ordering of the inhibition efficiencies from the highest to the least value in descending order of the inhibitor $(10 \mathrm{ml}<8 \mathrm{ml}<6 \mathrm{ml}<4 \mathrm{ml})$ for the time of immersion. The corrosion inhibition of the plant extract on the surface of mild steel may be due to presence of the phytochemical constituents such as $1.610 \mathrm{mg} / \mathrm{L}$ alkaloid, $0.672 \mathrm{mg} / \mathrm{L}$ flavonoid, $0.412 \mathrm{mg} / \mathrm{L}$ saponins, $0.124 \mathrm{mg} / \mathrm{L}$ tannins and $0.465 \mathrm{mg} / \mathrm{L}$ phenol in the extract [24]. From the plot, it can be seen that the inhibition efficiencies of varying concentrations begin to reduce after reaching the maximum at the initial or transient stage up to 6 minutes. This stage was preceded by the latency period [23]. This reduction may be due to the faster rate of corrosion resulting from breakaway of the oxide film formed from extract inhibitor adsorption into the metal surface. However, above 20 minutes exposure at all the inhibitor concentrations, the efficiencies become relatively steady due to the protective nature of the barrier film separating the metal surface from the acidic medium.

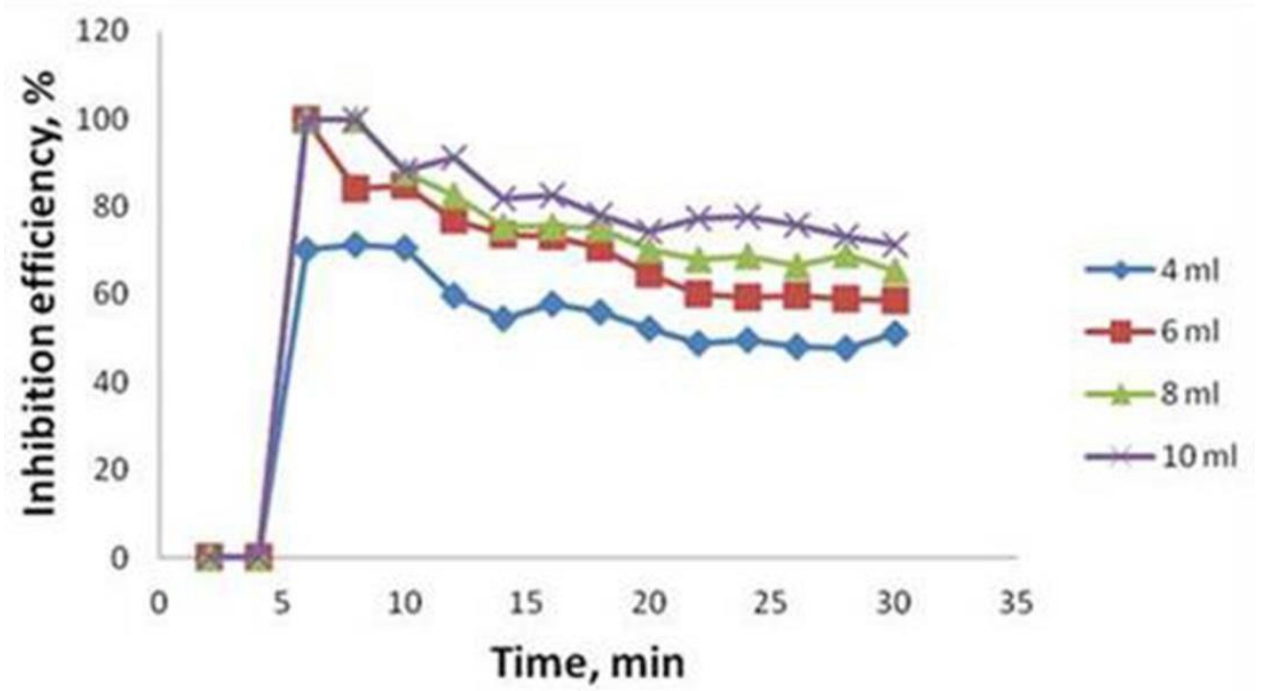

Figure 4. Variation of inhibition efficiency with the time of immersion in $4 \mathrm{M} \mathrm{H}_{2} \mathrm{SO}_{4}$. 


\section{Adsorption Isotherm}

Adsorption isotherms are very important in knowing the mechanism of inhibition of corrosion reaction of metals. The most frequently used adsorption isotherms are Frumkin, Temkin, Freundlich, Flory Huggins and Langmuir Isotherms. However, only Langmuir Isotherms is reported in the present study, while other adsorption methods were evaluated and reported elsewhere [26,27]. Langmuir gives an expression for the concentration to the degree of surface coverage $(\theta)$ according to Equation 3 [28]:

$$
C / \theta=1 / K_{\mathrm{ads}}+C
$$

Figures 5 and 6 represent the Langmuir isotherm plots of Jatropha Curcas leaves extract in both $\mathrm{HCl}$ and and $\mathrm{H}_{2} \mathrm{SO}_{4}$ aqueous solutions, respectively, showing the variation of $\mathrm{C} / \theta$ against $\mathrm{C}$ at 30 minutes exposure. The plots showed that Langmuir adsorption isotherm model is appropriate for the determination of the adsorption mechanism of the extract of Jatropha Curcas leaves in both acidic media, since the points were well fitted linearly (as indicated by the values of coefficient of correlation, $R^{2}$, as given in Table 1 ) at a fixed slope of 1 according to Equation 3 . The equilibrium constant of adsorption isotherm, $K_{\text {ads }}$, of the Jatropha Curcas leaf extract in both $\mathrm{HCl}$ and $\mathrm{H}_{2} \mathrm{SO}_{4}$ media were obtained from the intercept and the results are presented in Table 1 . However, due to the complexity of the compounds in the extracts of leaves of J. curcas [29], it is not possible to determine the exact molecular weight of the inhibitor and hence the concentration in $\mathrm{mol} \mathrm{dm}^{-3}$. As a result, values of the standard free energy of adsorption $\left(\Delta G_{\text {ads }}\right)$ in both media could not be calculated [30].

Table 1. Calculated values of Langmuir adsorption isotherm parameters of Jatropha Curcas extract in $\mathrm{HCl}$ and $\mathrm{H}_{2} \mathrm{SO}_{4}$ aqueous solution at 30 minutes

\begin{tabular}{ccccc}
\hline Plant Extract & $\begin{array}{c}\text { Concentration on } \\
\text { intercept point, } \mathbf{~ d ~ d m}^{-3}\end{array}$ & Slope & $\mathbf{K}_{\text {ads }} / \mathbf{~ g ~ d m}^{-3}$ & $\boldsymbol{R}^{\mathbf{2}}$ \\
\hline $\mathrm{JC}$ in $4 \mathrm{M} \mathrm{HCl}$ & 0.177 & 1.000 & 5.65 & 0.999 \\
\hline $\mathrm{JC}$ in $4 \mathrm{M} \mathrm{H}_{2} \mathrm{SO}_{4}$ & 0.206 & 1.000 & 4.85 & 0.995 \\
\hline
\end{tabular}

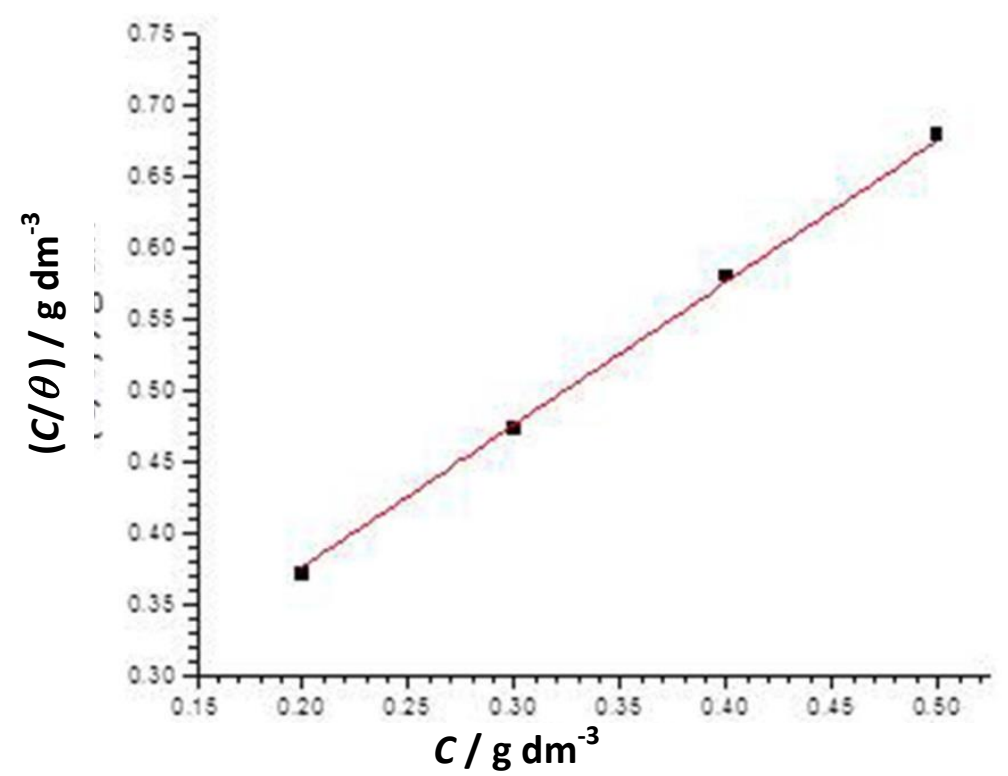

Figure 5. Langmuir isotherm for the adsorption of the extract of Jatropha leaves on the surface of mild steel in $4 \mathrm{M} \mathrm{HCl}$ at 30 minutes exposure. 


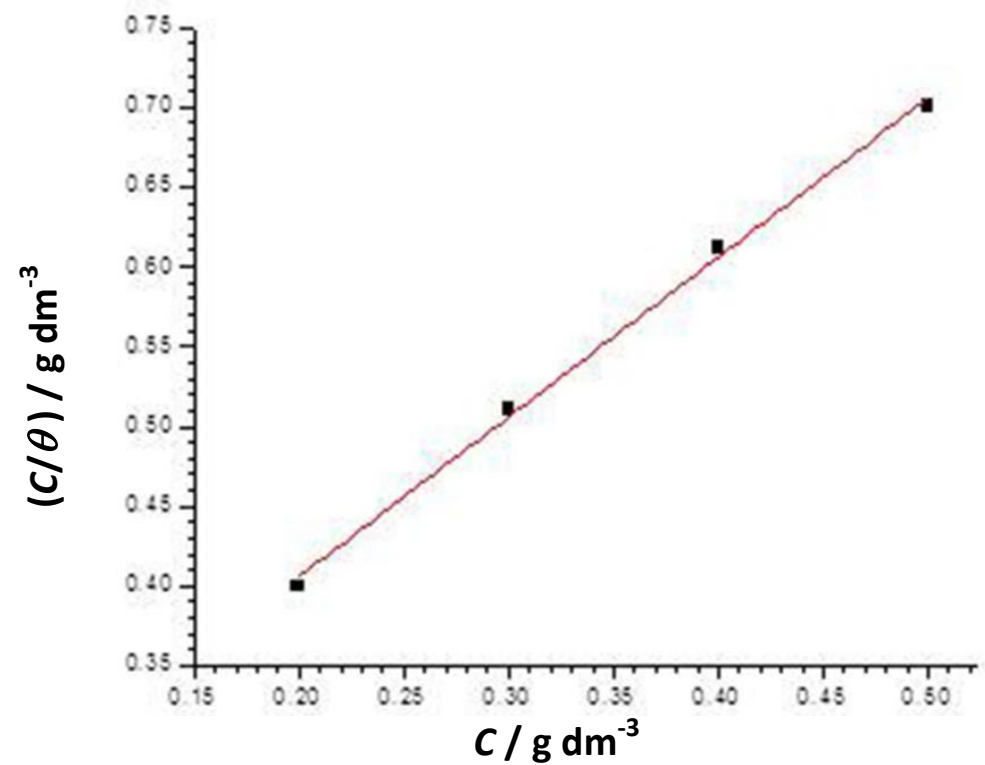

Figure 6. Langmuir isotherm for the adsorption of the extract of Jatropha leaves on the surface of mild steel in $4 \mathrm{M} \mathrm{H}_{2} \mathrm{SO}_{4}$ at 30 minutes exposure.

Plant extract contains organic compounds having polar atoms or groups which are adsorbed on the metal surface. Obot and Obi-Egbedi [13] reported that compounds interact by mutual repulsion or attraction when Ipomoea Involcrata plant extract was used as an inhibitor. This may be advocated as the reason for the slight departure of the slope values from unity as explained by Obot and Obi-Egbedi [13]. Although, in this study, the slope is fixed at 1 prior to linear fitting but few points were still slightly deviated from the straight line, which may be due to mutual repulsion or attraction of the polar atoms or groups as observed by Obot and Obi-Egbedi [13].

In addition, the adsorption of the Jatropha Curcas leaves extract on the mild steel surface may not involve the interaction of the adsorbate molecules with one another. According to Nnanna et al. [7], it was assumed that there was no interaction between the adsorbate molecules in the derivation of Langmuir isotherm. The adsorption was also assumed to be monolayer because the sites on the metal surface were taken to be energetically identical and uniformly distributed [8]. However, the adsorption process may be assumed to be due to an electrostatic interaction between the polar atoms/ions on the metal surface and the adsorbate molecules $[7,29]$.

\section{Conclusions}

- The leaf extract of Jatropha Curcas acts as a good and efficient inhibitor for corrosion of mild steel in $\mathrm{HCl}$ and $\mathrm{H}_{2} \mathrm{SO}_{4}$ solutions.

- Inhibition efficiencies of the Jatropha Curcas leaf extract in $\mathrm{HCl}$ medium were higher than those in $\mathrm{H}_{2} \mathrm{SO}_{4}$ environment. After 30 minutes exposure with extract concentration of $10 \mathrm{ml}$, the efficiency is $77.1 \%$ in $\mathrm{HCl}$ medium while $71.3 \%$ was obtained in $\mathrm{H}_{2} \mathrm{SO}_{4}$ medium.

- The inhibition of the corrosion of mild steel by acid extract of JC is due to the phytochemical constituents in the plant extract.

- The experimental data obtained at 30 minutes exposure in both $\mathrm{HCl}$ and $\mathrm{H}_{2} \mathrm{SO}_{4}$ solutions with Jatropha Curcas leaf extract were well fitted with the Langmuir adsorption isotherm indicating that the Langmuir adsorption model is applicable in the corrosion inhibition mechanism.

- Further work will be carried out using other techniques with micrographs from SEM to show the effect of temperature and/or $\mathrm{pH}$ on the corrosion efficiency of Jatropha Curcas leaf extract on mild steel and other materials. 


\section{References}

[1] J. R. Vimala, A. L. Rose, S. Raja, Int. J. ChemTech Res. 3 (2011) 1791-1801.

[2] P. B. Raja, M. G. Sethuraman, J. Pigment. Resin Technol. 38 (2009) 33-37.

[3] Corrosion costs and Preventive Strategies in the United States, http://www.cctechnologies.com (accessed $20^{\text {th }}$ January 2013).

[4] O. A. Omotosho, O. O. Ajayi, V. O. Ifepe, J. Mater. Environ. Sci. 2 (2011) 186-195.

[5] D. P. Rani, S. Selvaraj, Arch. App. Sci. Res. 2(6) (2010) 140-150.

[6] N. S. Patel, S. Jauhari, G.N. Mehta, Arab. J. Sci. Eng. 34 (2009) 61-69.

[7] L. A. Nnanna, V.U. Obasi, O. C. Nwadiuko, K. I. Mejeh, N. D. Ekekwe, S. C. Udensi, Arch. App. Sci. Res. 4 (2012) 207-217.

[8] O. M. Ndibe, M.C. Menkiti, M. N. C. Ijomah, O. D. Onukwuli, Electron. J. Environ. Agric. Food Chem. 10 (2011) 2847-2860.

[9] C. A. Loto, R.T. Loto, A.P.I. Popoola, Int. J. Phys. Sci. 6 (2011) 3689-3696.

[10] N. O. Eddy, Port. Electrochim. Acta. 27 (2009) 579-589.

[11] S. B. Ulaeto, U. J. Ekpe, M. A. Chidiebere, E. E. Oguzie, Int. J. Mater. Chem. 2 (2012) 158164.

[12] A. M. Al-Turkustani, S. T. Arab. Int. J. Chem. 2 (2010) 54-76.

[13] I. B. Obot, S. A. Umoren, N. O. Obi-Egbedi, J. Mat. Environ. Sci. 2 (2011) 60-71.

[14] C. A. Loto, J. Mater. Environ. Sci. 2 (2011) 335-344.

[15] K. P. V. Kumar, M.S.N. Pillai, G. R. Thusnavis, J. Mater. Sci. Technol. 27 (2011) 1143-1149.

[16] O. O. Ajayi, O. A. Omotosho, K. O. Ajanaku, O. O. Babatunde, J. Eng. App. Sci. 6 (2011) 1017.

[17] R. A. L. Sathiyanathan, S. Maruthamuthu, M. Selvanayagam, S. Mohanan, N. Palaniswamy, Int. J. Chem. Tech. 12 (2005) 356-360.

[18] R. Chauhan, U. Garg, R.K. Tak, E-Journal of Chemistry 8 (2011) 85-90.

[19] J. T. Nwabanne, V. N. Okafor, J. Emerg. Trends Eng. Appl. Sci. 2 (2011) 619-625.

[20] L. Jatropha Curcas, http://www.dovebiotech.com (accessed on 15 ${ }^{\text {th }}$ March 2013).

[21] M. A. Aisha, M. A. Nabeeh, Global Juornal of Science and Frontier Research Chemistry 12 (2012) 73-84.

[22] A. M. Al-Turkustani, S. T. Arab, R. H. Dahiri, Modern Applied Science 4 (2010) 105-124.

[23] Y. I. Kuznetsov, Russ. Chem. Rev. 73 (2004) 75-87.

[24] J. K. Odusote, O. M. Ajayi, J. Electrochem. Sci. Technol. 4 (2013) 81-87.

[25] O. M. Ajayi, M.Sc. Project Report, Department of Mechanical Engineering, University of Ilorin, Ilorin, Nigeria, 2013.

[26] N.O. Eddy, S.A. Odoemelam, A. J. Mbaba, Afri. J. Pure Appl. Chem. 2 (2008) 132-138.

[27] R. Staubmann, M. Schubert-Zsilavecz, A. Hiermann and T. Kartnig, Phytochemistry, 50 (1999) 337-338.

[28] S. Rekkab, H. Zarrok, R. Salghi, A. Zarrok, Lh. Bazzi, B. Hammouti, Z. Kabouche, R. Touzani , M. Zougagh, J. Mater. Environ. Sci. 3(2012) 613-627.

[29] E. E. Ebenso, N. O. Eddy and A. O. Odiongenyi, Afr. J. Pure Applied Chem. 2 (2008) 107-115.

(C) 2014 by the authors; licensee IAPC, Zagreb, Croatia. This article is an open-access article distributed under the terms and conditions of the Creative Commons Attribution license (http://creativecommons.org/licenses/by/3.0/) (cc) Br 